\section{「鳥取開墾社」広谷原入殖に関す る基礎史料 一その1 入殖予備調查史料について-}

\title{
A RESEARCH ON HISTORICAL DOCUMENTS OF OLD TOTTORI FEUDAL CLAN MAN'S FAMILIES NAMED TOTTORI RECLAMATION COMPANY, IMMIGRATED TO KOHRIYAMA WILDERNESS IN FUKUSHIMA
} -Part 1 On pre-surveied documents for
immigration-

狩野勝重 — $* 1$

キーワード

鳥取開塱社, 明治期，安積開留，移民，士族授産

Keywords :

Tottori Reclamation Company, In stage of Meiji government, Reclamation at ASAKA wilderness, Immigration, The National promotion of industry strategy for old clan man's families

\section{Katsushige KANO — $* 1$}

Old Tottori feudal clan man's families were immigrated at Asaka wilderness in Fukushima Prefecture for reclamation in early stage of Meiji government. That is decided for the Life foundation of Old Tottori feudal clan man's families and the National promotion of industry strategy. We have got the documents of Tottori Reclamation Company in Kohriyama City, Fukushima Prefecture. In this report, we will show the survey maps and architectural drawings in the documents and will define the early process of reclamation in Asaka wilderness, by verifying these documents.
初めに
現在の福島県郡山市北部に位置する広谷原で「鳥取開墾 社」が拘わった入殖関連の史料には、安積原野開墾のため に福島県が用意した測量関係図面類と、開墾社側が作成し た準備書類の 2 種類が存在することが判明しているが、そ うした資料の中から、当時の建設計画に拘わる史料を順次 明らかにして行こうとするものである。

なお、すでに報告済みの『「鳥取開墾社」の安積原野入殖 史料について』(2002 年建築学会大会学術講演梗概集)にお いて「鳥取開墾社」入殖当時の広谷原の区画割が、現在も 大きな変更は加えられていないことが確認された旨を報告 しているが、本稿は、その内容を更に詳細に展開させたも のであり、日本大学工学部建築学科佐藤平教授、松井壽則 助教授および同土木工学科知野泰明専任講師を含めた 4 人 による共同研究の中から、史的内容に限定して報告する。

\section{【I】安積原野開筀事業の概要と猪苗代疏水線計画図} 国営事業としての「福島県下岩代国安積郡字対面原及接 近諸原野開墾」が士族の授産事業として時の明治政府によ り強力に推し進められたことはよく知られる処であるが、 その契機となったのは、福島県が旧二本松藩士に対する士 族授産事業及び岩瀬・安積両郡に対する殖産事業として明 治五年 (1872) にスタートさせた大槻原開䛻事業であった。 しかし、旧二本松藩士の入殖が予定通りに進まなかったこ ともあって、郡山村商人達の力に依存する形の新田開発を 遒入することになった。それが安部茂兵衛を中心とした「開 成社」であり、周辺の入殖希望者を募り、誕生したのが桑 野村である。このような先行事例あったればこそ、明治十 年（1877）の安積諸原野開墾・猪苗代疏水開整事業部 1) が 国の授産・殖産事業として決定されるに至ったものと考え
られる。

明治十二年（1879）に猪苗代疎水事業が着工されるが、 その完成を前提として国営の安積諸原野開墾事業が遂行さ れることになる。明治十一年（1878）に大藏壇原に入殖し た「久留米開墾社」を手始めとして、明治十三年（1880） の「備前開墾」、明治十三〜+四年の「会津開墾社」（旧会 津藩）、広谷原「高知開墾社」と山田原「高知協力組!（旧 土住藩)、「棚倉開墾社」(旧棚倉藩)、明治 15 年 (1882) 牛 庭原開墾 (旧松山藩)、その他の旧士族達が相次いで移住す ることとなった。この計画は、当初2000戸を目論んでいた が、国の財政事情から大幅に縮小されることになり、結果 として総数 500 戸に落ち着いた。所謂「五百戸移住」と呼 ばれるものである。「鳥取開墾社」にあっても例外ではな く、入植が始まった明治十四年（1881）頃にはその計画が 更に縮小され、入殖戸数も当初の 365 戸から 78 戸人と変更 されている。

「鳥取開墾社」入殖は明治二十年（1887）をもつて一段落 するが、入殖初期にあっては、住宅の建設が間に合わず、 既設農家へ分宿するという状況であったと伝えられてい る。入殖者達は、明治十六年 (1883) 四月以降、広谷原の 割当て敷地に住宅建設が開始されるのを待って、順次移住 することになる註2)。

本稿で採り上げた「鳥取開墾社」準備書類は、郡山市喜 久田町堀之内にある宇倍神社から発見されたもので、現在 『鳥取開墾社関係文書』(郡山市 宇倍神社蔵・開成館収蔵) 註3) として保管されている。その内容は猪苗代疏水の計画 線図、広谷原の測量図、住戸配置に関する国許との遗り取 り、移住士住宅の基本平面図等々、多岐にわたっており、 明治十三年（1880）から奏施に移された国の政策に基づく 建築史・建築計画の立場から知りうる恰好の資料といえる。

*1 Prof., Department of Architecture, College of Engineering, Nihon Univ., Dr. Eng. 
ここでは、歴史的立場に限定して、入殖に至るまでの事前 調查に関する図面等史料について検証する。

『明治十三年六月 安積郡諸原野起業水利線路之図』につ いて

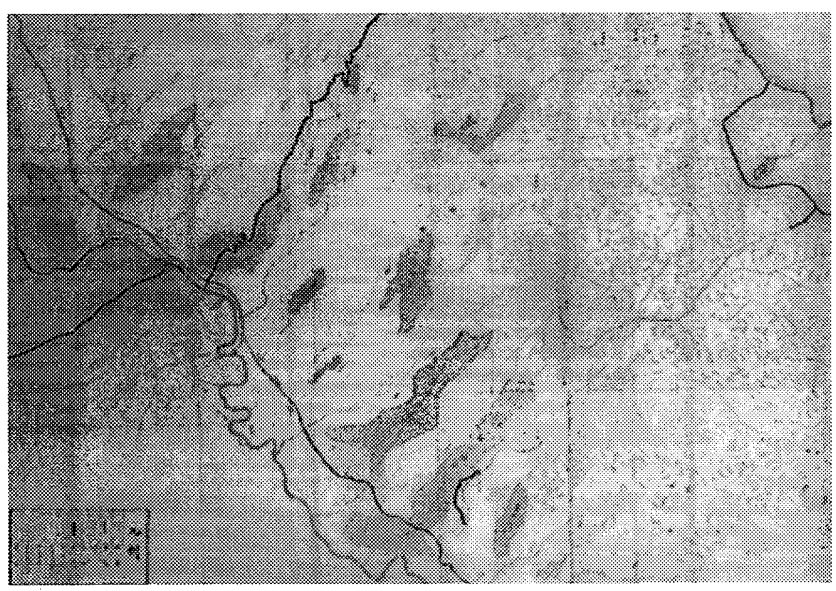

[図一 1]『明治十三年六月 安積郡諸原野起業水利之図』

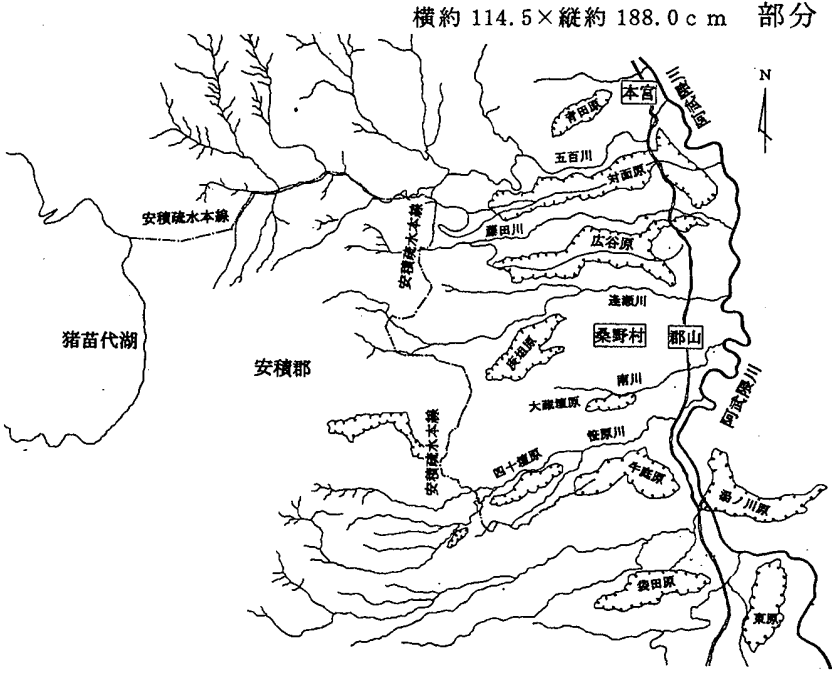

[図-2]『安積諸原野起業水利線路之図』より概要を示す

明治十一年 (1878) 当時の鳥取士族は、「恩賜之禄券モ過 半八他管へ移籍シ就産之輩十中ニ一二ヨ得ルニ至ラス是レ 誠二士族各自ノ不覚悟ニ八有之候得共一ツニハ土地ノ然ラ シムル者無キニシモ有ス・・・(中略)・・・今後数年 スシテ続々不可言之形状ヨ現出スルハ照然タルヘシト」註 4 というような情況であり、このような中で今井鉄太郎を中 心として「鳥取開墾社」は設立される。

明治十三年（1880）五月には「鳥取開墾社」の実質的指 導者である今井鉄太郎が現地調查を行うために広谷原に赴 いている。当初の計画における「鳥取開墾社」の入殖地は、

「久留米開墾社」註5)等と共に対面原をも視野に入れてい た節があるが、現実に入殖地として選んだのは広谷原であ った。

広谷原の現地調查に赴いた際、今井が最初に入手したと 思われる資料が『明治十三年六月 安積郡諸原野起業水利 線路之図』(『鳥取開墾社関係文書』整理 No. 399) [図1]（その概要を示したのが[図－2 ] ）である。この絵図に は、猪苗代湖を始めとした 7 つの湖沼、逢涱川（阿武郎川） を含む中小の河川、奥州街道、16 に及ぶ安積諸原野、安積 郡の村々、周辺峰々が描かれる他、猪苗代疏水の本線とな

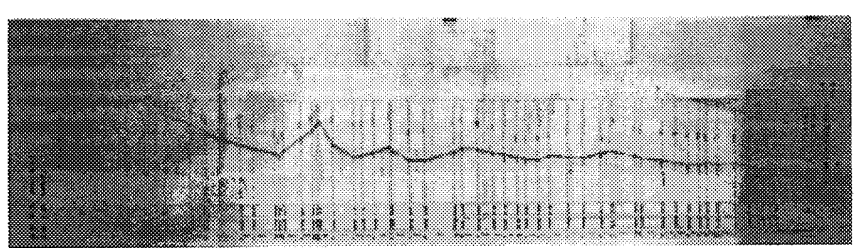

[図一 - 3 ] 『猪苗代湖 $コ$ 安積郡諸原野高低実測図明治十 一年二月実測』横約 $180.0 \times$ 縦約 $51.5 \mathrm{~cm}$ るべき予定水路図が描かれているものの、等高線は描かれ ておらず、安積諸原野概要絵図ともいうべきものである。 恐らく、本絵図の作成は、明治十一年二月に内務省勧農局 森本義俱および福島県十等属伊藤直記によって作成された 『猪苗代湖ヨリ安積郡諸原野高低実測図』(郡山市安積 疏水土地改良区蔵）裎 6)【図-3】の継続作業として精查が 求められた中で描かれたものと考えられよう。このような 図面類が整備されていく過程を類推させる史料に『渋谷吉 蔵安積開拓事務測量日誌』待7) がある。『日誌』に拠れば、 明治十一年七月三十一日に大江測量掎一同が童村から北 へ高低差測量を開始し、十二月十八日には「横山祐作氏牛 庭原江向テ鏈測」と記すのを最後に一応の測量を終えてい る。その間の図面作成に関する記録だけを抜粋すると下記 のようなものであった。

（九月）四日 終日諸原野諸図手伝之事

十日 十軒原実測 但し高低測量

十五日 白川布ノ引平面 見取製図 $O O_{(\text {( ) }}$ )

タメニ改正スルラ不得

十六日 会津郡 平面図之事

十七日 午前製図之事

十九日 会津郡平面製図之事

二十一日 諸原野表之事

二十二日 会津郡写図之事

二十三日 会津郡写図之事

二十四日 午前会津郡写図

その後、二十五日より再び野田新田村（猪苗代湖南岸近 辺）と水

面の高低差測量から郡山南方諸原野の測量に移っている。 この大江測量挂一同の調查は、『猪苗代湖ヨリ安積郡諸原 野高低実測図』を基にして更に詳細な測量が行われたこと を推測させるが、その結果が『会津郡平面図』を基にした 猪苗代疏水本線の決定一と媻がり、『明治十三年六月 安 積郡諸原野起業水利線路之図』に認められたものと考えて よかろう。『日誌』の十一月二十五日の条には次のように見 えている。

$$
\begin{aligned}
& \text { 午後一万二千分ノ一製図之事社 8) } \\
& \text { 一一万千分ノ一製図落成直二写図可 } \\
& \text { 致候段南君 } コ \text { 御申聞ノ事 }
\end{aligned}
$$

その縮尺からすると、このときに作成された図面と『安 積郡諸原野起業水利線路之図』はほぼ一致する。すなわち、 渋谷吉蔵のいう『会津郡平面図』とは『安積郡諸原野起業 水利線路之図』の元図を指すものと考えられる。福島県は、 安積開墾事業を推進するに当たって詳細な測量図面を用意 していくが、入殖先行調查隊の今井等が入手した原野図は このような情況のもとに作成された初期的測量図であり、 等高線などは描かれておらず、必ずしも詳細な検討をする のに適当なものであったとは考えられない。しかし、未だ、 この時点では広谷原の詳細測量図は作成されておらず、今 
井等は、概略図によって検討せざるを得なかったものと推 測される。

\section{【II 】広谷原入殖淮備と配置計画草稿絵図}

明治十四年の入殖に当たっては、移住士50戸の中に農業 の指導的役割を担う老農 2 戸、医者 1 戸、大工鍛冶を始め とした職人若干戸を含むべきことというように『開墾規則 十六条』によって規定されるが、実際に確認できるのは、 大工が杉本六三郎 1 名、老農は古河金一・尾阪生八・福田 亀十郎・高田庄平の 4 名であった。広谷原開墾に当たって 入殖者に用意された宅地は 43 、「番外」と記され、「上等移 住士」として趣いたものと思われる吉田、石井、山村の 3 戸および橋本、厩および明地の一つを含めて 48。その中で 「下等移住士」（旅費・家屋建築費・開䛻費とも拝借）とし て広谷原に趣いたのは仙石吉衛を除く 41 戸であった。『鳥 取開坆社関係文書』の中には、各敷地における移住士住宅 の配置計画から、建前順を示した図までが含まれているこ とから、本稿では、その時の様子を時系列的に確認するこ とを目的として、『第四十九号諸絵図面類 鳥取開墾社 委員』(明治十四年四月『鳥取開墾社文書』整理-No. 29 袋 共 21 葉 縦約 $37.0 \mathrm{c} \mathrm{m}$ 横約 $18.5 \mathrm{c} \mathrm{m}$ の和紙袋入) 所収の 拝借家屋配置絵図（無題）の中、[図-4、5、6、7]に 示した 4 葉の家屋配置計画図を今後の研究の基礎史料とし て、その史料内容を詳らかにしようとするものである。

『配膡計画草稿絵図一』(仮題)

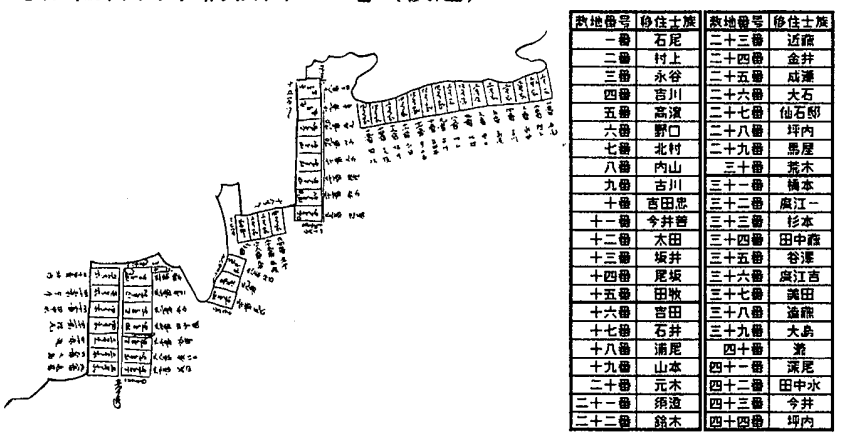

[図-4]『配㯰計画草稿一』横約 $30.0 \times$ 綎約 $42.0 \mathrm{~cm}$

本絵図は図面名・年季ともに欠くが、広谷原入殖の居住 区域のみを示したもので、厩を含む 45 の敷地全てに移住予 定者が書込まれて、敷地内に書込まれた住宅種別には朱疃 で確認が入れられている。

移住士の入居予定敷地がどのような経緯を辿ってこのよ うな配置を採ったかという点については「䈅引」というの が基本的手法であるが、「盞方 うな記述も見え、事実上どのような手順で決定されたのか は判らない。絵図は現地踏查によるか既存の字限図を写し 採ったものであろうが、いずれにしろ本絵図が移住士住宅 の配置に関する最初の計画図であったと推定される。因み に、[図ー4、6、7]は同一原図を使用したものとみられ る。

\section{『「統計四十三戸外二仙石邱 7 含内一戸八廍」配固絵図』}

(仮題)

本絵図も図面名・年季ともに久いているが、図面下部の 書き込みによって『統計四十三戸外二仙石邱 嘅」配置絵図』(仮題) と呼ぶことにする。この絵図に描か れた内容を見ると、北東隅の節上原に壱号から十五号まで の 15 戸、中央の傳左エ門原に十六号から三十号までの 15
戸と厩、傳左エ門原傳左エ門原の西側に位置する堀ノ内原 に三十一号から四十四号までの 14 户、総数 44 戸の移住士 住宅および一つの厩が配されている。こうした図中の家屋 番号ならびに屋根・道路等に関する書込みは大方朱墨で、 「甘三号」、「甘四号」、「廿八号」、「井号」の文字は黒墨の 上に朱耊でなぞってあり、「外二仙石邸

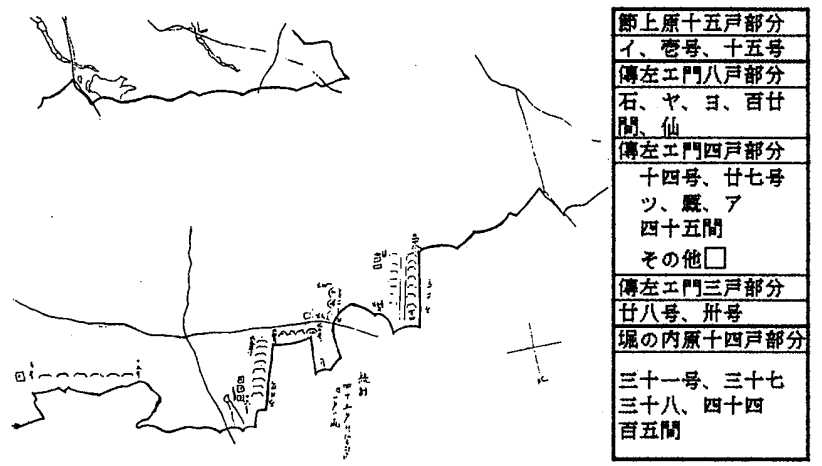

[図-5]『「統計四十三戸外二仙石邸 7 含内一戸八厩」配置 絵図』横約 $30.0 \times$ 縦約 $42.0 \mathrm{~cm}$

黒墨によるものである。明治十四年四月『鳥取開墾社文書』 整理-No.29 の中には『廣谷原略圖』と書かれた原野絵図と 同等の図面が 4 枚程含まれているが、本絵図はそうした図 面の内から移住区域に関係する部分だけを写し採ったもの と考えられる。また、絵図中の口で囲った書き込み文字は、 節上原の「イ」二石尾のことを指し、傳左エ門原は「石」 二石井、「巾」=山村、「ヨ」=吉田のこと、その他、傳左 エ門原の「ア」=荒木、「ッ」＝坪内のことを指しているも のと考えられる。これらは、『配膡計画草稿絵図一』で示 された移住計画に対して追加・変更等の検討を指示してい るのではないかと推測される。

『配置計画草稿絵図 二』(仮題)

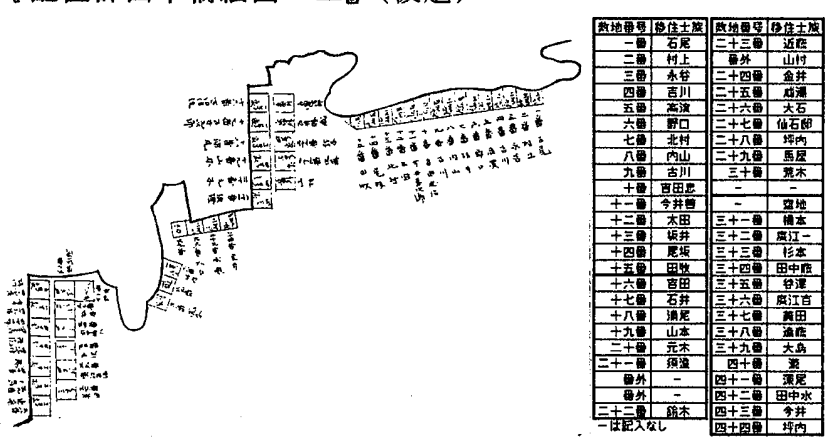

[図-6]『配置計画草稿絵図 二』横約 $30.0 \times$ 綎約 $42.0 \mathrm{~cm}$

本絵図もまた図面名・年季ともに欠いている。図面の性 格としては前出の『配置計画草稿絵図一』と同様のもの で、敷地内に書込まれた住宅種別には朱筆で認められてい る。描き込み内容を確認すると、傳左エ門原十六番から二 十三番までに番外として吉田保次郎、石井勝蔵、山村宇太 郎の 3 名が追加されて、それによって、傳左エ門原の南北 五閒道路に接する宅地は、五間道路を挟んで東側に 5 軒、 西側に 6 軒が配置されるといら形に変更されて『統計四十 三戸外二仙石邸 7 含内一戸八厩」配置絵図』の書き込みと 一致していることから、『配置計画草稿一』に対する追加 指示によった変更結果を示しているものと考えられる。そ の後の『配置計画草稿 三』でも傳左エ門原の南北五間道 路に接する宅地（配置の中央十六番から二十四番にあたる 部分）が一文字 8 軒ではなく、本絵図による道路を挟んだ 
配置計画変更を踏襲している。なお、三十一番から三十七 番の敷地については、『配置計画草稿 一』のなかで、三十 一番東に敷設された空地に三十一番を移すことにより北側 に一番づつ繰り上げる形をとっている。

『配置計画草稿絵図 三』(仮題)

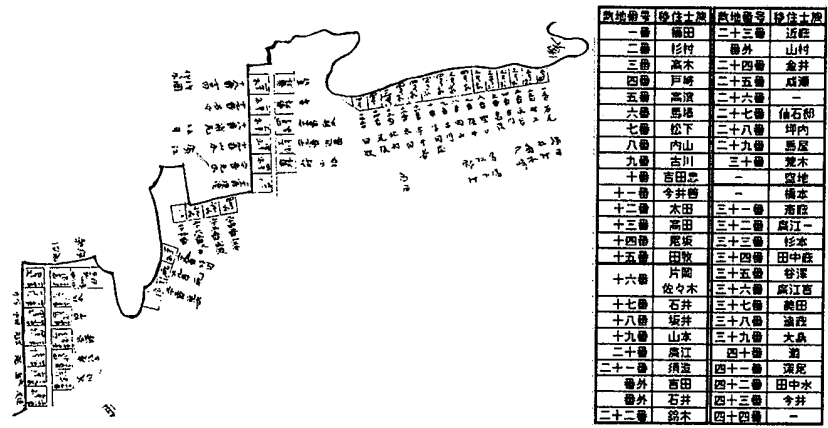

[図-7]『配置計画草稿絵図 三』横約 $30.0 \times$ 繸約 $42.0 \mathrm{c} \mathrm{m}$

本絵図もまた表題および年季を欠く。『配置計画草稿絵図 二』に、更に欄外の朱筆書き込みによって変更が加えられ ているのを知ることができる。『配置計画草稿絵図 二』と の更なる明確な違いは、二十七番の仙石の名前が消えてい ることと、傳左エ門原の南端三十番の南に空地（地番なし） を追加していることである。しかし、この絵図による朱筆 変更後の入殖者氏名は『明治廿年 措借家屋居住人名並番 号』(郡山市 宇倍神社蔵・開成館収蔵) に記録された家屋 拝借者の宅地番号とほぼ一致しているので、恐らく、これ が一応の決定稿と考えてよかろう。

ところで、明治十四年三月の今井鉄太郎の入殖を皮切り に、一部の者を除き明治十四年中に治殆ど移住を済ませて いるが、傳左ェ門原二十一番と二十二番の間に予定されて いた番外の吉田保次郎ならびに二十三番の次の番外に予定 されていた山村宇太郎は明治十四年（1881）八月に除籍を 願い出ている。このことからすると、本絵図の訂正書き込 みは明治十四年四月以降、八月に吉田保次郎が除籍を願い 出て片岡・佐々木の両名に変更になる以前ということにな る。因みに、片岡・佐々木の両名の入殖は、明治十五年 (1882) 八月のことであった。

【III】第四十九号 諸絵図面類 鳥取開榞社委員』所収 の拝借家屋配置絵図の史料的位置付けについて

「鳥取開墾社」の安積原野移住に関しては、『社中規則並 二申合書類』(『鳥取開貏社関係文書』)の「申合セヶ目」 を見ると、下記のように記されている。

一 規則更正之事

一 三十戸増員願御指合之次第

一 福島表ヨリ順次報送ノ次第

一 仙石吉衛来鳥ノ事

一 家屋建築手続ノ事

一 居宅組合を尋る事

一 原野図面を以テ宅地ノ景況 $コ$ 示シ、吉衛、元興居 地 $ᄏ$ 談ズル事

一 宅地番号籤引ノ義二就而者続キ屋敷等ノ䈅方 談シテ抽籤致ス事

一 番号整頓ノ上福島へ向ケ決定ノ事由 部分は漢字がないので別字を宛てた)

すなわち、福島に赴いた今井等から鳥取に送られる指示 書類に対して、合議の上決定事項を書面にて返送という手
順が明らかになる。しかし、『鳥取開墾社関係文書』の多く は年季を欠くばかりでなく、史料同士の関連性も明らかに されていない。そうした中で、本稿で採り上げた『配置計 画草稿 一』から『配置計画草稿 三』に至る 4 葉の絵図 類は、鳥取士族授産事業の中で「鳥取開墾社」が安積入殖 の手順を具体化していく初期経過を明らかにし得る数少な い史料の一つと位置付けられると同時に、『鳥取開既社関係 文書』に納められたその他の関連史料を分析していくため の糸口になるものと考えられる。

そのような観点から、各敷地における建物配置や建前之 順を記した図面、あるいは、明治十六〜二十年 $(1883 \sim 1887)$ における家屋拝借証などについても、整理がつき次第その 史料内容を順次報告していく予定である。なお、紙面の関 係から図を大きく揭載できなかったため、図中記載内容を 表にして示すこととした。

なお、本報告を縞めるにあたって、郡山市教育員会文化 課、開成館、安積疏水土地改良区の皆々様、ならびに、そ の他数多の関係諸氏に大変お世話になりましたこと、記し て感謝の意を表します。

補註

註 1)「安積諸原野開墍」は正式には「福帛県下岩代国安穔郡字对面 原及接近諸原野開蒩」と称され、「安樌硫水」も当時の名称は「猪 苗代硫水」であった。

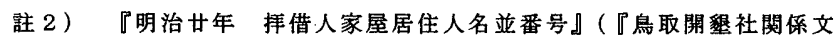
書』）飞扰れば、家屋择借年月日は明治十六年以降となっており、 初期は近村の農家に仮住まいをしていたと伝えられる(伝開)。

註 3 ）平成十一年七月、郡山市喜久田町伝左工閒原の旧坪内家住宅発 見と同時に同町宇倍神社から発見されたもので、明治十四年から始

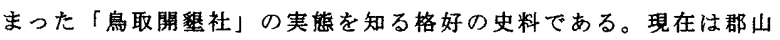
市開成館に収藏されている。正式な名称は付けられていないが、便 宜上『鳥取開曁社関係文書』としておく。

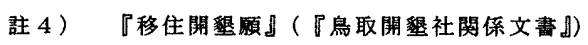
明治十三年七月に烏取県下因蟠国邑美郡今町住の今井鉄太郎が、 時の鳥取県知事境二郎宛に提出した願畫の一部である。

註 5)『第四拾九号諸絵図面類鳥取開㙆社委員』明治十四年四月 (『鳥取開墾社関係文書』) 所收の諸記録絵図の中に対面原の絵図が 含まれている。図中には前田沢北部に「久留米社」の大きな書き込 みがみられる。位置は異なるが「久留米開秏社」は対面原東部に入 殖している。あるい性当初詨面原入殖を予定していたが、中条政恒 の意向によって大藏墥原に変更されたといわれる「久留米社」のこ とであろう。

註 6)『猪苗代湖ヨリ安積郡諸原野高低実测図』

(郡山市 安稹硫水土地改良区蔵)

この测量図は横軸が 1/36,000、縦軸が 1/1,000 というように繸

横で維尺が異なり、レベルの差が判り易いような表現となっている。

註 7) 知野泰明・藤田龍之が『猪苗代湖硫水（安樌硫水）事業におけ る測量日誌に関する研究』(土木史研究第 19 号 1999 年 5 月)で

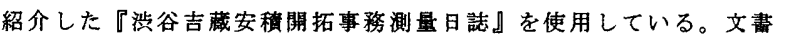
の題名は同論文による。山潟村は猪苗代湖水の東岸に位置する村で、 湖水から幾部もない山間部に田子沼があった。

註 8) 全体の測量図は「一万二千分ノ一」で仕上げられ、高低差につ いては『猪苗代湖ヨリ安稹郡諸原野高低実測図』(前揭史料)のよう に、水平軸とはそのスケールを変えていたものと推测される。 [2003年 3 月12日原稿受理 2003年 7 月29日採用決定］ 